\title{
PLANT BIOMONITORING: IMPACT OF URBAN ENVIRONMENT ON SEASONAL DYNAMICS OF STORAGE SUBSTANCES AND CHLOROPHYLLS OF OLEANDER
}

\author{
M.S. MELETIOU-CHRISTOU ${ }^{1, *}$ \\ G.P. BANILAS ${ }^{2}$ \\ C. BARDIS ${ }^{1}$ \\ S. RHIZOPOULOU ${ }^{1}$
}

\author{
${ }^{1}$ Department of Botany, Faculty of Biology \\ National and Kapodistrian University of Athens \\ Athens 15784, Greece \\ ${ }^{2}$ Department of Enology and Beverage Technology, Faculty of \\ Food Technology and Nutrition \\ Technological Educational Institute of Athens, Greece
}

Received: $17 / 02 / 11$

Accepted: $31 / 10 / 11$ *to whom all correspondence should be addressed: e-mail: mmeleti@biol.uoa.gr

\begin{abstract}
In the present study seasonal changes of chlorophyll content and storage substances related to the metabolic response of the widespread, evergreen plant oleander (Nerium oleander) to air pollution were investigated. Mature leaves of oleander shrubs, grown at five sites of differing levels of air pollution in the center and the suburbs of the Athens Metropolitan area, were examined during the course of a year. Soluble sugars, starch and total lipid content of the leaves showed a peak at the end of the cold season, while a decline was detected during the main growth period. Leaf chlorophyll content was increased during spring. It seems likely that the level of air pollution in Athens did not affect the concentration and the seasonal pattern of storage substances at the leaf level. Elevated chlorophyll content was estimated in the polluted with oxides of nitrogen sites. In contrast, leaf chlorophyll content declined in sites with ozone pollution.
\end{abstract}

KEYWORDS: air pollution; carbohydrates; chlorophylls; city; lipids; Nerium oleander.

\section{INTRODUCTION}

The effect of air pollution on plants has been the subject of many studies under laboratory and field conditions. Several parameters have been examined at the leaf level, which are related with morphology (Eleftheriou, 1987), ultrastructure (Psaras and Christodoulakis, 1987; Christodoulakis and Fasseas, 1990; Christodoulakis, 1993), growth and development (Whitmore et al., 1985), photosynthesis (Lendzian and Unsworth, 1983) and chlorophyll fluorescence (Lanaras et al., 1994; Sgardelis et al., 1994). Although numerous indoor laboratory studies related with effects of individual pollutants on plants have been published, outdoor studies with mixed gaseous pollutants are rare (Lendzian and Unsworth, 1983). In the filed, plants are invariably exposed to complex mixtures of pollutants, which do vary both in time and space (Barnes and Wellburn, 1998; Mahmooduzzafar et al., 2006).

Plants' response to air pollution depends on their metabolic activity and the developmental stage of the tissues, the season and climatic conditions (Lendzian and Unsworth, 1983; Treshow and Anderson, 1991). Reduction in growth of vascular species by air pollution is preceded by changes in physiological processes; for example, inhibition of photosynthesis and alteration in chlorophyll content was detected under exposure to air pollutants (Srivastava, 1998; Lima et al., 2003; Joshi and Swami, 2009; Calder et al., 2010). Lipids as major components of cellular membranes are particularly influenced by environmental conditions including air pollutants (Harwood, 1994). Plants respond to air pollutants via direct and indirect costs (Barnes and Wellburn, 1998), while different defense strategies may vary from one species to another (Wellburn and Wellburn, 1996). In considering the eastern Mediterranean, previous studies with laurel and olive (Christodoulakis and Faseas, 1990; Christodoulakis and Koutsogeorgopoulou, 1991) showed that morphological and 
ultrastructural leaf characteristics, which enable the species to withstand stress conditions of the dry season, may also count for their ability to tolerate air pollution. Also, carbohydrates stored as reserves enable plants to survive under stress conditions and facilitate their recovery (Iwasa and Kubo, 1997; Wyka, 1999; Meloche and Diggle, 2003). While, the largest part of the mobile organic carbon fraction in vascular plants falls into non-structural carbohydrates (soluble sugars and starch) and lipids (Körner, 2003).

Oleander (Nerium oleander L.) is an evergreen, sclerophyll shrub, widespread in the Mediterranean Basin, which grows under both sun and shade conditions. This plant species withstands drought, heat, winds, air pollution and salt spraying. In contrast, in regard to frost susceptibility it is among the most sensitive Mediterranean species (Larcher, 1981; Larcher, 2000). It has been argued that the species can be used for biomonitoring of heavy metal and air pollution in Mediterranean region (Aksoy and Öztürk, 1997; Culotta et al., 2005). Recently, oleander has been repeatedly used in landscaping, because of its ornamental value and a capacity to acclimate the prolonged dry season of the Mediterranean ecosystem.

The main objective of this work was to study the effect of air pollution on the annual fluctuations of storage substances and on chlorophyll content of a Mediterranean plant grown in polluted areas, associated with different air pollutants, in order to understand acclimation mechanisms at physiological and biochemical level. Oleander was found to grow in numerous sites of urban environments; this plant is exposed to a gradient of air pollutants, from the center to the suburbs of the city of Athens. Air quality and climatic parameters of Athens metropolitan area have been the subject of different investigations (Tzanakou and Deligiorgi, 2006; Polymeneas and Pilinis, 2008). To the best of our knowledge annual fluctuations of nonstructural carbohydrates and lipids have not been investigated in the leaves of oleander grown in air-polluted sites. Our attempt was to evaluate whether leaves of oleander expanded under different quantitatively and qualitatively levels of air pollution exhibit comparable, seasonal concentrations of chlorophyll content, carbohydrates and lipids. A secondary objective was to investigate a physiological parameter of plant growth that might be used as biomarker for monitoring air pollution.

\section{AREA DATA AND METHODS}

\section{Description of the study area}

The metropolitan area of Athens expands in an arid mountainous basin, which is divided northsouth by a line of hills. The mountains surrounding the city of Athens reduce air circulation, causing accumulation of pollution over the city (Polymeneas and Pilinis, 2008). Monitoring air pollution has revealed that elevated values of $\mathrm{SO}_{2}, \mathrm{NO}_{2}$ and $\mathrm{CO}$ were measured in the center of Athens, while greater values of $\mathrm{O}_{3}$ were observed in the suburbs in comparison to the center of the city (Table 1). Thus, vegetation grows in a burdened environment. The experiment was conducted in four different sites of the city of Athens namely P (Patission: $37^{\circ} 60^{\prime} \mathrm{N}, 23^{\circ} 44^{\prime} \mathrm{E}$ ), AU (Agricultural University: $37^{\circ} 59^{\prime} \mathrm{N}, 23^{\circ} 42^{\prime} \mathrm{E}$ ), R (Renti: $37^{\circ} 57^{\prime} \mathrm{N}, 23^{\circ} 40^{\prime} \mathrm{E}$ ), and NS (Nea Smyrni: $37^{\circ} 55^{\prime} \mathrm{N}, 23^{\circ} 43^{\prime} \mathrm{E}$ ), where concentrations of air pollutants were measured by the Ministry of the Environment Energy and Climate Change (Table 1). Another site S (Spata: $\left.37^{\circ} 58^{\prime} \mathrm{N}, 23^{\circ} 55^{\prime} \mathrm{E}\right)$, close to Athens International Airport, was chosen for comparison; in this site corresponding values of $\mathrm{NO}_{2}$ and $\mathrm{O}_{3}$ (Table 1) were obtained from measurements performed by the Society for the operation of Athens International Airport (AIA). Climatic data of the closest to the sampling sites meteorological stations are shown in Figure 1.

\section{Plant material}

Mature leaves from seven years old shrubs of oleander (Nerium oleander L., Apocynaceae) without any visible symptoms of injury were sampled at monthly intervals during the course of a year. The shrubs received the same watering (three times per week during the dry summer and once a week during the winter) and fertilizing treatment (once a year).

Plant material was collected early in the morning $(06.00 \mathrm{~h}$ in the summer, $07.00 \mathrm{~h}$ in the winter) to avoid diurnal variations (Wink and Carey, 1994). Thirty fully expanded leaves were randomly collected from each site. The samples were brought to the laboratory, dried and stored as described elsewhere (Meletiou-Christou et al., 1994). 
Table 1. Mean $\mathrm{SO}_{2}$, Smoke, $\mathrm{NO}, \mathrm{NO}_{2}$ and $\mathrm{O}_{3}\left(\mu \mathrm{g} \mathrm{m}^{-3}\right)$ and $\mathrm{CO}\left(\mathrm{mg} \mathrm{m}^{-3}\right)$ values at the experimental sites of Athens metropolitan area

\begin{tabular}{|c|c|c|c|c|c|c|c|c|c|c|c|c|}
\hline \multirow{2}{*}{ Months } & $\mathrm{SO}_{2}$ & $\mathrm{CO}$ & Smoke & NO & $\mathrm{NO}_{2}$ & $\mathrm{O}_{3}$ & $\mathrm{SO}_{2}$ & $\mathrm{CO}$ & Smoke & NO & $\mathrm{NO}_{2}$ & $\mathrm{O}_{3}$ \\
\hline & \multicolumn{6}{|c|}{$P$ site } & \multicolumn{6}{|c|}{$A U$ site } \\
\hline Mar. & 51 & 4.0 & 73 & 109 & 78 & 34 & 21 & 1.5 & - & 69 & 52 & 49 \\
\hline Apr. & 39 & 4.4 & 86 & 142 & 113 & 30 & 18 & 1.8 & - & 51 & 44 & 62 \\
\hline May & 41 & 5.1 & 95 & 149 & 113 & 25 & 28 & 1.2 & - & 17 & 36 & 55 \\
\hline Jun. & 17 & 4.0 & 95 & 122 & 110 & 41 & 23 & 0.8 & - & 25 & 42 & 75 \\
\hline Jul. & 33 & 3.7 & 89 & 100 & 112 & 47 & 26 & 1.0 & - & 27 & 47 & 81 \\
\hline Aug. & 29 & 3.4 & 81 & 71 & 95 & 41 & 17 & 1.0 & - & 36 & 39 & 75 \\
\hline Sep. & 39 & 5.1 & 121 & 137 & 107 & 20 & 15 & 1.2 & - & 56 & 30 & 50 \\
\hline Oct. & 31 & 5.1 & 99 & 157 & 93 & 23 & 15 & 1.8 & - & 31 & 41 & 32 \\
\hline Nov. & 55 & 6.7 & 111 & 197 & 90 & 15 & 21 & 2.1 & - & 93 & 61 & 24 \\
\hline Dec. & 56 & 6.4 & 107 & 185 & 74 & 16 & 19 & 2.4 & - & 84 & 42 & 21 \\
\hline Jan. & 54 & 4.4 & 73 & 112 & 65 & 22 & 24 & 1.9 & - & 31 & 37 & 32 \\
\hline Feb. & 61 & 5.1 & 90 & 143 & 80 & 28 & 25 & 1.8 & - & 49 & 48 & 40 \\
\hline \multicolumn{7}{|c|}{ NS site } & \multicolumn{6}{|c|}{ S site } \\
\hline Mar. & 55 & 1.4 & 21 & 28 & 60 & 35 & - & - & - & - & 29 & 73 \\
\hline Apr. & 20 & 1.5 & 18 & 32 & 58 & 55 & - & - & - & - & 28 & 86 \\
\hline May & 37 & 1.6 & 17 & 23 & 59 & 54 & - & - & - & - & 22 & 91 \\
\hline Jun. & 41 & 1.5 & 15 & 12 & 46 & 70 & - & - & - & - & 17 & 100 \\
\hline Jul. & 30 & 1.1 & 15 & 31 & 46 & 81 & - & - & - & - & 11 & 111 \\
\hline Aug. & 33 & 1.3 & 10 & 14 & 38 & 81 & - & - & - & - & - & . \\
\hline Sep. & 16 & 1.4 & 11 & 32 & 34 & 60 & - & - & - & - & 17 & 63 \\
\hline Oct. & 49 & 2.2 & 19 & 45 & 60 & 31 & - & - & - & - & 19 & 67 \\
\hline Nov. & 65 & 2.1 & 30 & 46 & 44 & 30 & - & - & - & - & 15 & 56 \\
\hline Dec. & 59 & 2.7 & 35 & 45 & 42 & 21 & - & - & - & - & 11 & 57 \\
\hline Jan. & 47 & 1.8 & 24 & 32 & 43 & 29 & - & - & - & - & 15 & 56 \\
\hline Feb. & 57 & 2.2 & 28 & 47 & 47 & 27 & - & - & - & - & 24 & 64 \\
\hline \multicolumn{7}{|c|}{$R$ site } & & & & & & \\
\hline Mar. & 17 & 1.9 & 16 & 16 & 29 & 55 & & & & & & \\
\hline Apr. & 20 & 1.6 & 25 & 31 & 50 & 62 & & & & & & \\
\hline May & 13 & 1.5 & 19 & 26 & 43 & 72 & & & & & & \\
\hline Jun. & 13 & 1.2 & 21 & 44 & 40 & 84 & & & & & & \\
\hline Jul. & 13 & 0.6 & 17 & 30 & 57 & 97 & & & & & & \\
\hline Aug. & 9 & 0.8 & 12 & 10 & 28 & 88 & & & & & & \\
\hline Sep. & 11 & 1.2 & 13 & 16 & 36 & 73 & & & & & & \\
\hline Oct. & 15 & 1.8 & 23 & 28 & 43 & 54 & & & & & & \\
\hline Nov. & 20 & 2.2 & - & 58 & 42 & 40 & & & & & & \\
\hline Dec. & 12 & 1.2 & 22 & 49 & 47 & 28 & & & & & & \\
\hline Jan. & 27 & 2.9 & 49 & 68 & 47 & 38 & & & & & & \\
\hline Feb. & 29 & 2.3 & 49 & 64 & 55 & 39 & & & & & & \\
\hline
\end{tabular}

\section{Methods}

Soluble sugars were determined according to Dubois et al. (1956). Starch was measured using the method of McCready et al. (1950). Total lipids were extracted and determined according to Bligh and Dyer (1959). Chlorophyll (Chl) a, b and total Chl were determined by a method described by Steubing (1965). The ratio of Chl a versus Chl b was calculated. The results are means of three replicates \pm standard error (S.E.).

\section{Data analysis}

All data were checked for normality (using $\alpha=0.05$ or $\alpha=0.01$ ) prior to statistical analyses. Results of soluble sugars, starch, lipids and chlorophylls were subjected to two-way analyses of variance (ANOVA) among sites and months ( $p$-level<0.00000). Duncan's multiple range test was used for comparison of means at $5 \%$ probability. Discriminant foreword stepwise function analysis was used to determine which parameter discriminates among sites. 


\section{RESULTS}

The annual patterns of soluble sugars in the leaves of oleander from five different air polluted sites are shown in Figure 2A. An increase of soluble sugar content was detected, in all sites, between November and December $(p<0.05)$ and elevated levels of sugars were sustained until March (Figure 2A). In spring and as the growth season of the species proceeded soluble sugar content started to decline; at the sites $\mathrm{R}, \mathrm{AU}$ and $\mathrm{S}$ the decrease was observed earlier in the season than at $\mathrm{P}$ and NS.

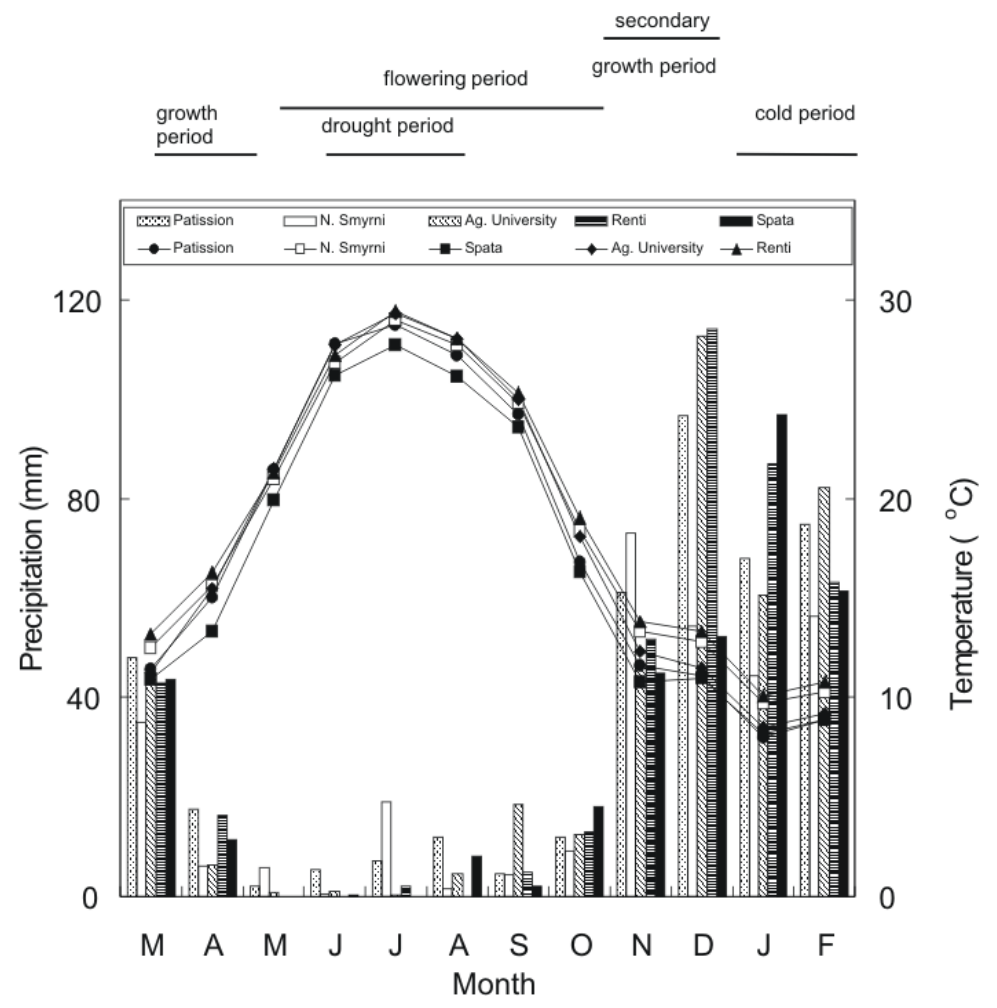

Figure 1. Climatic data of the closest to each sampling site meteorological station, throughout the study period; the order of months is from March up to February. Continuous lines represent mean monthly temperature and bars represent the total, monthly precipitation

The annual fluctuations of starch accumulation in the leaves of oleander were similar in all sites (Figure 2B); maxima of starch content were observed at the end of the cold season (Figure 2B). During spring, which coincides with the main growth period of native Mediterranean plants, starch concentrations decreased and the decline continued up to the summer; starch concentrations did not show considerable changes during the drought season and until October, when the climatic conditions were again favorable for growth (Figure 2B). Starch started to accumulate in leaves of oleander from November, at the onset of the cold period, and reached maxima in March.

The fluctuations of total lipids were similar in all sites (Figure 3). A decline of total lipids was observed during the main growth period in spring. Total lipid concentrations did not show considerable changes during summer, while in late autumn, as the temperature decreased (Figure 1), an increase of total lipids was observed, which continued throughout the winter. A higher capacity of lipid storage was observed at site $S$ towards the end of the cold season.

The concentration of total chlorophyll increased during late spring and early summer in mature leaves of oleander (Figure 4A). Furthermore, total chlorophyll reached significantly higher values at site $P$ in the city center during the year, in comparison to the other sites $(p<0.001)$, and the maximum value was recorded in July. As it is shown from the ratio of $\mathrm{Chl}$ a/b (Figure 
4B), high $\mathrm{Chl}$ content detected at site $\mathrm{P}$ was due to increased concentration of both $\mathrm{Chl}$ a and Chl b.

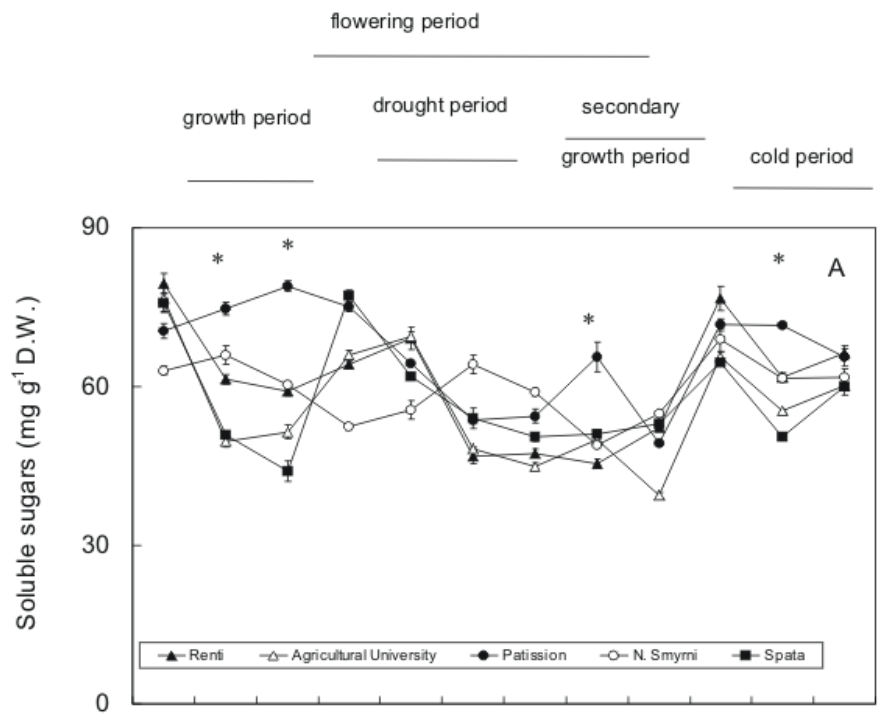

Figure 2. Annual fluctuations of foliar soluble sugar $(A)$ and starch (B) content, in five sampling sites. Vertical bars represent S.E. of the means; S.Es ranging from 0.00 to $0.06 \mathrm{mg} \mathrm{g}^{-1}$ are not presented. Asterisks $\left({ }^{*}\right)$ indicate statistically significantly difference of the means between $P$ site and each of the other sites, within the given month $(p<0.001)$
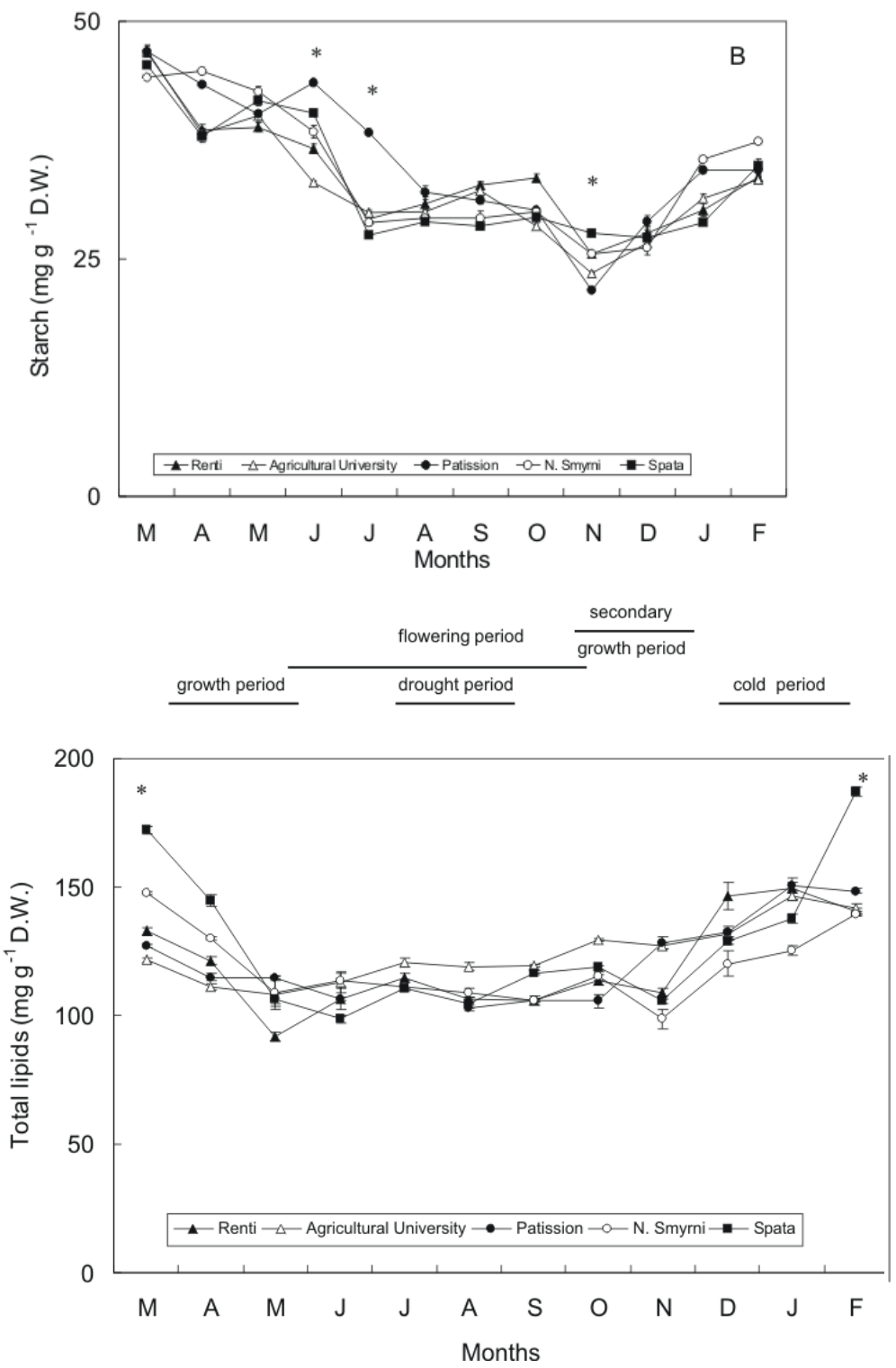

Figure 3. Annual fluctuation of foliar lipid content in five sampling sites; vertical bars represent S.E. of the means. Asterisks $\left({ }^{*}\right)$ indicate statistically significantly difference of the means between $S$ site and each of the other sites, within the given month $(p<0.001)$ 
Discriminant foreword stepwise function analysis based on the variation of soluble sugars, starch, lipids and total chlorophyll determined each month from each of the five sampling sites (Table 2) showed that chlorophyll contributed more to the discrimination among sites in the leaves of oleander, followed by soluble sugars and total lipids, whereas starch did not contribute to the discrimination among sites.

Table 2. Results of Discriminant foreword stepwise function analysis of foliar soluble sugar, starch, lipid and chlorophyll content among sites; statistical significance at $p<0.05\left(^{*}\right)$ and $p<0.001\left(^{* *}\right)$ is indicated

\begin{tabular}{lrc}
\hline Parameter & F-value & p-level \\
\hline Chlorophylls & 19.086 & $* *$ \\
Lipids & 2.430 & $*$ \\
Sugars & 4.751 & $* *$ \\
Starch & 0.4083 & n.s. \\
\hline
\end{tabular}

\section{DISCUSSION}

\section{Soluble sugars and Starch}

In spring, fluctuations of soluble sugars were significantly different among sites, during the main growth period. Taking into consideration that, oleander shrubs received the same treatment (watering, fertilizing) in the research sites, this difference in fluctuation may be due either to different microclimatic conditions, which does not arise from meteorological data (Figure 1), or to different air quality. The elevated values of soluble sugars detected during summer in other Mediterranean shrubs (Meletiou-Christou et al., 1994; 1998; Palacio et al., 2007) were not distinguished in leaves of oleander, which is in accordance with results from other Mediterranean evergreen sclerophyll species (Rhizopoulou et al., 1989; Meletiou et al., 1994).

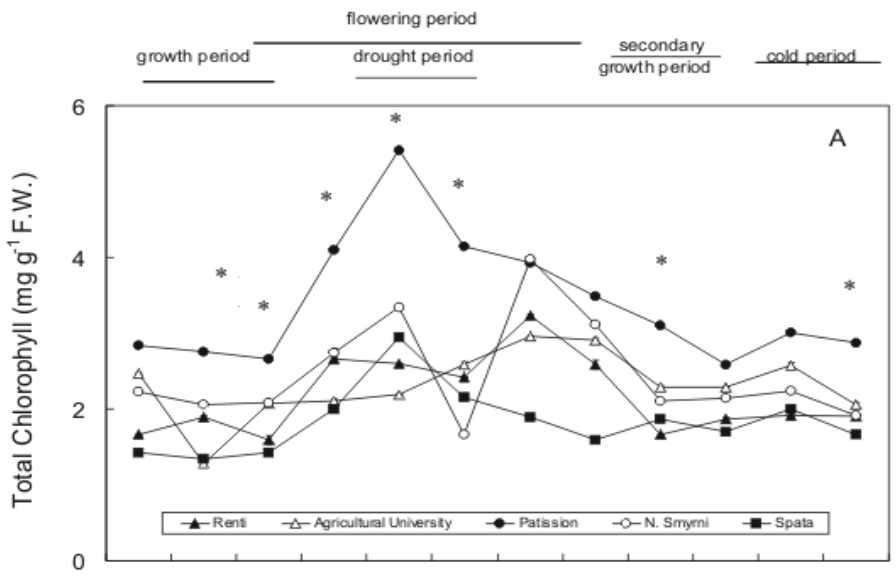

Figure 4. Foliar Chl content $(\mathrm{A})$ and $\mathrm{Chl} \mathrm{a} / \mathrm{b}$ ratios $(B)$ of oleander in five sampling sites during the course of a year; S.E. of the means ranged from 0.00 to $0.03 \mathrm{mg} \mathrm{g}^{-1}$. Asterisks $\left(^{*}\right)$ indicate statistically significantly difference of the means between $P$ site and each of the other sites, within the given month $(p<0.001)$

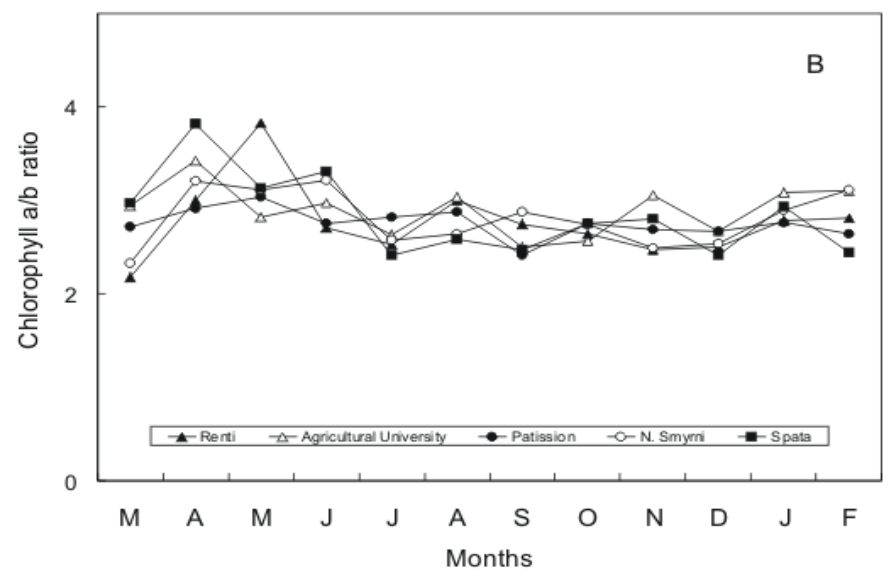


The annual fluctuations of starch in the leaves of oleander from all the sites (Figure 2B) were characteristic of the patterns found for other Mediterranean evergreen sclerophylls (MeletiouChristou et al., 1994; Körner, 2003). Starch decreased in spring (i.e. during the main growth period), it did not show considerable changes during the prolonged dry season and it was accumulated from November up to March. The accumulation of starch from November until March, concomitantly with the increase of soluble sugars and lipids, could be due to climatic conditions during autumn (rainfall and temperature), permitting elevated carbon fixation equal to the spring levels and continuing during mild winter conditions (Nunes et al., 1992; Larcher, 2000; Körner, 2003). Growth was restricted during this period in spite of continued carbon fixation (Rhizopoulou et al., 1991; Nunes et al., 1992). A second weak peak was recorded in October at the end of the dry season, which is in accordance to earlier investigations, indicating a lesser depression on photosynthesis than on structural growth (Körner, 2003). The decrease of foliar starch that was recorded between October and November in all sites seems to be related to a secondary growth period exhibited by Mediterranean evergreen sclerophylls in late autumn (Mitrakos, 1980; Rhizopoulou et al., 1991; Larcher 2000). Furthermore, the prolonged flowering period of oleander, which started in late spring and lasted until late autumn, and fruit maturation during autumn might contribute to the decrease of foliar starch concentration during this period.

Our results indicated that the annual cycle of foliar starch storage was similar in all sites. However, in June and July starch concentration in leaves of oleander was statistically significantly higher at site $P$ in comparison to the other sites $(p<0.001)$. This accumulation of starch at site $P$, towards the end of the growth period, in parallel to the increase of total chlorophylls may suggest either that the microclimatic conditions at site $\mathrm{P}$ restricted growth, or that recent photosynthates were produced in excess of the demands for growth and as a result carbohydrates were accumulated at this time and were consumed later.

\section{Lipids}

It is likely that leaves of oleander accumulate substantial amounts of lipids, comparable to those estimated for other Mediterranean plants, i.e. strawberry trees and olive trees (Larcher and Thomaser-Thin, 1988; Meletiou-Christou et al., 1994). The annual fluctuations of total lipids had great similarities with those of starch as it occurs in other Mediterranean evergreen species (Larcher and Thomaser-Thin, 1988; Meletiou-Christou et al., 1994). Lipids were accumulated from November up to March i.e. during the cold period, when growth was restricted and were consumed during the growth period. It has been suggested that the annual storage cycle of lipids is primarily subjected to endogenous control and it reacts to drastic environmental stress conditions, such as drought and frost (Larcher and Thomaser-Thin, 1988). On the other hand, it has been reported that air pollutants altered the amounts of stored lipids and affected lipid content and metabolism (Harwood, 1994). According to our results the annual fluctuations of total lipids in oleander leaves were similar in all sites. The high capacity of lipid storage during the cold season and up to March at site S (Figure 3) could be related to lower temperatures by $2{ }^{\circ} \mathrm{C}$ to $3{ }^{\circ} \mathrm{C}$ in comparison with the other sites, which was recorded during the whole experimental period (Figure 1).

\section{Chlorophylls}

Assessment of leaf chlorophyll content provides information on plant physiological status and might be a valuable tool for agricultural and ecosystem studies, since it is closely linked to nitrogen content and, hence, to photosynthesis (Serrano, 2008 and references therein).

It has been argued that leaves of plants exposed to elevated $\mathrm{NO}_{2}$ appeared greener than those of normal ambient conditions (Whitmore et al., 1985); also, the components of organic nitrogen increased in $\mathrm{NO}_{x}$ studies (Srivastava et al., 1995). Taking into consideration that at site $\mathrm{P}$ higher concentrations of $\mathrm{NO}$ and $\mathrm{NO}_{2}$ were recorded in comparison to the other sites (Table 1), it seems likely that the conditions of this site favor the synthesis of chlorophyll in the leaves of oleander. In the other sites higher values of $\mathrm{O}_{3}$ concentrations and lower values of $\mathrm{NO}$ and $\mathrm{NO}_{2}$ were measured in comparison to site $\mathrm{P}$ (Table 1). $\mathrm{O}_{3}$ concentrations seem to affect chlorophyll 
content, as it has been published in early studies and leaves exposed to $\mathrm{O}_{3}$ usually appear chlorotic (Whitmore et al., 1985). Oleander shrubs used in the present investigation did not show any visible symptoms of injury and they are considering as adapted to the environmental pollution. It has been argued that high ozone concentrations reported in Mediterranean areas represent a limited threat to native plant species. Probably this is due to the high foliar concentrations of ozone defense compounds. Also, ozone summer peaks coincide with soil water deficits and stomatal closure, which reduces the impact ozone (Ashmore, 2005 and references therein). However, the anatomical characteristics of oleander indicate stomata in crypts (Hassiotou et al., 2009; 2010), resulting in elevated stomatal conductance during the prolonged summer drought period, affecting the leaf water status and the maintenance of turgor pressure (Rhizopoulou and Wagner, 1995; Badger et al., 2006; Meletiou-Christou and Rhizopoulou, unpublished data).

\section{Conclusions}

The annual fluctuations of soluble sugars, starch and total lipids in the leaves of oleander showed maxima at the end of the cold season and declined during the main growth period. It is also indicative that leaves of oleander accumulated substantial amounts of lipids. The level of air pollution in the city of Athens did not affect the concentration and the seasonal pattern of storage substances (carbohydrates and lipids). While, an effect was detected in the chlorophylls' content, which was found higher in the more polluted with oxides of nitrogen sites and lower in sites with increasing ozone pollution. It is likely that determination of chlorophylls may be used as a "marker" for biomonitoring ozone pollution. A general and practical conclusion of the present study is that oleander shrubs are well suited to tolerate urban air pollution (such as found in Athens) as it has been suggested for other Mediterranean landscapes (Fernández Espinosa and Rossini Oliva, 2006; Niu et al., 2006) and can, therefore, be used in urban landscaping.

\section{ACKNOWLEDGEMENTS}

Thanks are due to the Ministry of Environment, Energy and Climate Change, AIA and the National Meteorological Service for providing aerial pollutants' and climatic data.

\section{REFERENCES}

Aksoy A. and Öztürk M.A. (1997), Nerium oleander L. as a biomonitor of lead and other heavy metal pollution in Mediterranean environments, Science of the Total Environment, 205, 145-150.

Ashmore M.R. (2005), Assessing the future global impacts of ozone on vegetation, Plant, Cell and Environment, 28, 949-964.

Badger M.R., Björkman O., and Armond P.A. (2006), An analysis of photosynthetic response and adaptation to temperature in higher plants: temperature acclimation in the desert evergreen Nerium oleander L., Plant Cell and Environment, 5. 85-99.

Barnes J.D. and Wellburn A.R. (1998), Air pollutant combinations, In: Responses of Plant Metabolism to Air Pollution and Global Change, De Kok, L.J. and Stulen I. (Eds), Backhuys Publishers, Leiden.

Bligh E.G. and Dyer W.J. (1959), A rapid method of total lipid extraction and purification, Canadian Journal of Biochemistry and Physiology, 37, 911-917.

Calder J.W., Lifferth G., Moritz M.A. and Clair S.S.B. (2010), Physiological effects of smoke exposure on deciduous and conifer tree species, International Journal of Forestry Research, 2010, Article ID 438930, 7 p., doi:10.1155/2010/438930.

Christodoulakis N.S. (1993), Air pollution effects on the guard cells of the injury resistant leaf of Laurus nobilis L., Bulletin of Environmental Contamination and Toxicology, 51, 471-478.

Christodoulakis N.S. and Fasseas C. (1990), Air pollution effects on the leaf structure of Laurus nobilis, an injury resistant species, Bulletin of Environmental Contamination and Toxicology, 44, 276-281.

Christodoulakis N.S. and Koutsogeorgopoulou L. (1991), Air pollution effects on the leaf structure of two injury resistant species: Eucalyptus camaldulensis and Olea eu-ropaea L. var. sylvestris Brot., Bulletin of Environmental Contamination and Toxicology, 47, 433-439. 
Culotta L., Gianguzza A, and Orecchio S. (2005), Leaves of Nerium oleander L. as bioaccumulators of polycyclic aromatic hydrocarbons (PAH) in the air of Palermo (Italy): extraction and GC-MS analysis, distribution and sources, Polycyclic Aromatic Compounds, 25, 327-344.

Dubois M., Gilles K.A., Hamilton J.K., Rebers P.A. and Smith F. (1956), Colorimetric method for determination of sugars and related substances, Analytical Chemistry, 28, 350-356.

Eleftheriou E.P. (1987), A comparative study of the leaf anatomy of olive trees growing in the city and the country, Environmental and Experimental Botany, 27, 105-117.

Fernández Espinosa A. J. and Rossini Oliva S. (2006), The composition and relationships between trace element levels in inhalable atmospheric particles (PM10) and in leaves of Nerium oleander L. and Lantana camara L., Chemosphere, 62, 1665-1672.

Hassiotou F., Evans J.R., Ludwig M. and Veneklaas E.J. (2009), Stomatal crypts may facilitate diffusion of $\mathrm{CO}_{2}$ to adaxial mesophyll cells in thick sclerophylls, Plant Cell and Environment, 32, 1596-1611.

Hassiotou F., Renton M., Ludwig M., Evans J.R. and Veneklaas E.J. (2010), Photosynthesis at an extreme end of the leaf trait spectrum: how does it relate to high leaf dry mass per area and associated structural parameters, Journal of Experimental Botany, 61, 3015-3028.

Harwood J.L. (1994), Environmental factors which can alter lipid metabolism, Progress in Lipid Research, 33, 193-202.

Joshi P.C. and Swami A. (2009), Air pollution induced changes in the photosynthetic pigments of selected plant species, Journal of Environmental Biology, 30, 295-298.

Iwasa Y. and Kubo T. (1997), Optimal size of storage for recovery after unpredictable disturbances, Evolutionary. Ecology, 11, 41-65.

Körner C. (2003), Carbon limitation in trees, Journal of Ecology, 91, 4-17.

Lanaras T., Sgardelis S.P. and Pantis J.D. (1994), Chlorophyll fluorescence in the dandelion (Taraxacum spp.): a probe for screening urban pollution, Science of the Total Environment, 149, 61-68.

Larcher W. (1981), Low temperature effects on Mediterranean sclerophylls: an unconventional viewpoint, In: Components of Productivity of Mediterranean Regions Basic and Applied Aspects, Margaris N. and Mooney H.A. (Eds), Dr Junk, The Hague.

Larcher W. (2000), Temperature stress and survival ability of Mediterranean sclerophyllous plants, Plant Biosystems, 134, 279-295.

Larcher W. and Thomaser-Thin W. (1988), Seasonal changes in energy content and storage patterns of Mediterranean sclerophylls in a northernmost habitat, Acta Oecologica/Oecologia Plantarum, 9, 271-283.

Lendzian K.J. and Unsworth M.H. (1983), Ecophysiological effects of atmospheric pollutants, In: Encyclopedia of Plant Physiology, 12D, Lange O.L., Nobel C.B., Osmond C.B. and Ziegler H. (Eds), Springer-Verlag, Berlin.

Lima W., Jarvis P. and Rhizopoulou S. (2003), Stomatal responses of five commercially important Eucalyptus species to elevated $\mathrm{CO}_{2}$ concentrations and soil water stress, Scientia Agricola, 60, 231-238.

Mahmooduzzafar V.R.B., Siddici T.O. and Iqbal M. (2006), Foliar response of Ipomea pes-tigridis L. to coal-smoke pollution, Turkish Journal of Botany, 30, 413-417.

Mc Cready R.M., Guggolz J., Silviera V. and Owens M.S. (1950), Determination of starch and amylose in vegetables, Analytical Chemistry, 22, 1156-1158.

Meletiou-Christou M.S., Rhizopoulou S. and Diamantoglou S. (1994), Seasonal changes of carbohydrates, lipids and nitrogen content in sun and shade leaves from four Mediterranean evergreen sclerophylls, Environmental and Experimental Botany, 34, 129-140.

Meletiou-Christou M.S., Banilas G.P. and Diamantoglou S. (1998), Seasonal trends in energy contents and storage substances of the Mediterranean species Dittrichia viscosa and Thymelaea tartonraira, Environmental and Experimental Botany, 39, 21-32.

Meloche C.G. and Diggle P.K. (2003), The pattern of carbon allocation supporting growth of preformed shoot primordia in Acomastylis rossii (Rosaceae), American Journal of Botany, 90, 1313-1320.

Mitrakos K.A. (1980), A theory for Mediterranean plant life, Acta Oecologica/ Oecologia Plantarum, 1, 245-252.

Niu G., Rodriguez D.S., Cabrera R., McKenney C. and Mackay W. (2006), Determining water use and crop coefficients of five woody landscape plants, Journal for Environmental Horticulture, 24, 160165.

Nunes M.A., Ramalho J.D.C. and Rijo P.S. (1992), Seasonal changes in some photosynthetic properties of Ceratonia siliqua (carob tree) leaves under natural conditions, Physiologia Plantarum, 86, 381387. 
Palacio S., Maestro M. and Montserrat-Martí G. (2007), Seasonal dynamics of non-structural carbohydrates in two species of Mediterranean sub-shrubs with different leaf phenology, Environmental and Experimental Botany, 59, 34-42.

Polymeneas P. and Pilinis C. (2008), Athens air quality and importance of biogenic emissions: a case study, Global NEST Journal, 10, 151-160.

Psaras G.K. and Christodoulakis N.S. (1987), Air pollution effects on the ultrastructure of Phlomis fruticosa mesophyll cells, Bulletin of Environmental Contamination and Toxicology, 38, 610-617.

Rhizopoulou S., Angelopoulos K. and Mitrakos K. (1989), Seasonal variations of accumulated ions, soluble sugars and solute potential in the expressed sap from leaves of evergreen sclerophyll species, Acta Oecologica/Oecologia Plantarum, 10, 311-319.

Rhizopoulou S., Meletiou-Christou M.S. and Diamantoglou S. (1991), Water relations for sun and shade leaves of four Mediterranean evergreen sclerophylls, Journal of Experimental Botany, 42, 627-635.

Rhizopoulou S. and Wagner E. (1995), Fumigation with $\beta$-pinene disrupts turgor of Picea abies needle tips, Environmental and Experimental Botany, 35, 235-240.

Serrano L. (2008), Effects of leaf structure on reflectance estimates of chlorophyll content, International Journal of Remote Sensing, 29, 5265-5274.

Sgardelis S., Cook C.M., Pantis J.D. and Lanaras T. (1994), Comparison of chlorophyll fluorescence and some heavy metal concentrations in Sonchus spp. and Taraxacum spp. along an urban pollution gradient, Science of the Total Environment, 158, 157-164.

Srivastava H.S. (1998), Metabolic responses of plants to nitrogen oxides, In: Responses of Plant Metabolism to Air Pollution and Global Change, De Kok, L.J. and Stulen, I. (Eds), Backhuys Publishers, Leiden.

Srivastava H.S., Ormrod D.P. and Halle B.A. (1995), Assimilation of nitrogen dioxide by plants and its effects on nitrogen metabolism, In: Nitrogen Nutrition in Higher Plants, Srivastava H.S. and Singh R.P. (Eds), Associated Publ. Co., New Delhi.

Steubing L. (1965), Pflanzenökologisches Praktikum, Verlag Paul Parey, Berlin.

Treshow M. and Anderson F.K. (1991), Plant Stress from Air Pollution, John Wiley and Sons, Chichester, New York.

Tzanakou M. and Deligiorgi D. (2006), Trends of the daily maximum temperatures in relation with the climatic change and the urbanization in the Athens basin, Global NEST Journal, 8, 186-194.

Wellburn A.R. and Wellburn F.A.M. (1996), Variable patterns of antioxidant protection but similar ethylene emission differences in several ozone-sensitive and ozone-tolerant plant selections, Plant, Cell and Environment, 19, 754-760.

Whitmore M.E., Davies W.J. and Mansfield T.A. (1985), Air pollution and leaf growth, In: Control of Leaf Growth, Baker, N.R., Davies, W.J. and Ong, C.K. (Eds), Cambridge University Press, Cambridge.

Wink M. and Carey D.B. (1994), Variability of quinolizidine alkaloid profile of Lupinus argenteus (Fabaceae) from North America, Biochemical Systematics and Ecology, 22, 663-669.

Wyka T. (1999), Carbohydrate storage and use in an alpine population of the perennial herb, Oxytropis sericea, Oecologia, 120, 198-208. 